University of Nebraska - Lincoln

DigitalCommons@University of Nebraska - Lincoln

\title{
Long-rotation sugarcane in Hawaii sustains high carbon accumulation and radiation use efficiency in 2 nd year of growth
}

\author{
Ray G. Anderson \\ USDA, San Joaquin Valley Agricultural Sciences Center and U.S. Salinity Laboratory, \\ ray.anderson@ars.usda.gov \\ Rebecca Tirado-Corbalá \\ USDA, San Joaquin Valley Agricultural Sciences Center \\ Dong Wang \\ USDA, San Joaquin Valley Agricultural Sciences Center \\ James E. Ayars \\ USDA, San Joaquin Valley Agricultural Sciences Center, james.ayars@ars.usda.gov
}

Follow this and additional works at: https://digitalcommons.unl.edu/usdaarsfacpub

Anderson, Ray G.; Tirado-Corbalá, Rebecca; Wang, Dong; and Ayars, James E., "Long-rotation sugarcane in Hawaii sustains high carbon accumulation and radiation use efficiency in 2nd year of growth" (2014). Publications from USDA-ARS / UNL Faculty. 1464.

https://digitalcommons.unl.edu/usdaarsfacpub/1464

This Article is brought to you for free and open access by the U.S. Department of Agriculture: Agricultural Research Service, Lincoln, Nebraska at DigitalCommons@University of Nebraska - Lincoln. It has been accepted for inclusion in Publications from USDA-ARS / UNL Faculty by an authorized administrator of DigitalCommons@University of Nebraska - Lincoln. 


\title{
Long-rotation sugarcane in Hawaii sustains high carbon accumulation and radiation use efficiency in 2 nd year of growth
}

\author{
Ray G. Anderson ${ }^{a, b, *}$, Rebecca Tirado-Corbaláa ${ }^{\text {, Dong Wang }}{ }^{a}$, James E. Ayars ${ }^{\text {a }}$ \\ a USDA, Agricultural Research Service, San Joaquin Valley Agricultural Sciences Center, Water Management Research Unit, 9611 S. Riverbend Ave. Parlier, CA, \\ 93648-9757, USA ${ }^{1}$ \\ ${ }^{\mathrm{b}}$ USDA, Agricultural Research Service, U.S. Salinity Laboratory, Contaminant Fate and Transport Unit, 450 W. Big Springs Rd., Riverside, CA, 92507-4617, USA ${ }^{2}$
}

\section{A R T I C L E I N F O}

\section{Article history:}

Received 15 June 2014

Received in revised form 8 September 2014

Accepted 10 September 2014

Available online $\mathrm{xxx}$

\section{Keywords:}

Saccharum officinarum $\mathrm{L}$.

Hawaii

Eddy covariance

Net ecosystem productivity

Radiation use efficiency

2nd generation biofuel production

\begin{abstract}
A B S T R A C T
Sugarcane has been a major agronomic crop in Hawaii with an unique, high-yield, two-year production system. However, parameters relevant to advanced, cellulosic biofuel production, such as net ecosystem productivity (NEP) and radiation use efficiency (RUE), have not been evaluated in Hawaii under commercial production. Recent demand potential has rekindled interest in Hawaiian grown biofuels; as such, there is a need to understand productivity under changing climate and agronomic practices. To this end, we established two eddy covariance towers in commercial sugarcane fields in Maui, Hawaii to evaluate the carbon balance and RUE of sugarcane under contrasting elevations and soil types. We combined the tower observations with biometric and satellite data to assess RUE in terms of net biomass accumulation and daily gross primary production. High, sustained net NEP was found in both fields (cumulative NEP 4.23-5.37 $\times 10^{3} \mathrm{~g} \mathrm{C} \mathrm{m}^{-2}$ over the course of the measurement period). Biomass RUE was statistically similar for both fields (1.15-1.24 g above ground biomass per MJ intercepted solar irradiance). Carbon accumulated in both fields at nearly the same rate with differences in cumulative biomass due to differing crop cycle lengths; cumulative gross primary productivity and ecosystem respiration were higher in the lower elevation field. Contrary to previous studies in Hawaiian sugarcane, we did not see a large decrease in NEP or increase in ecosystem respiration in the 2nd year, which we attributed to suppressed decomposition of dead cane stalks and leaves due to drip irrigation and drought. Biomass RUE also showed little decline in the 2nd year. The results show that Hawaiian sugarcane has a higher productivity than sugarcane grown in other regions of the world and also suggests that a longer (>12 months) growing cycle may be optimal for biomass production.
\end{abstract}

Published by Elsevier B.V.

\section{Introduction}

Sugarcane is one of the most advantageous agronomic crops for biofuels due to its high productivity, efficiency, and return on

\footnotetext{
${ }^{1}$ Note: The U.S. Department of Agriculture (USDA) prohibits discrimination in all its programs and activities on the basis of race, color, national origin, age, disability, and where applicable, sex, marital status, familial status, parental status, religion, sexual orientation, genetic information, political beliefs, reprisal, or because all or part of an individual's income is derived from any public assistance program. (Not all prohibited bases apply to all programs.).

2 Persons with disabilities who require alternative means for communication of program information (Braille, large print, audiotape, etc.) should contact USDA's TARGET Center at (202) 720-2600 (voice and TDD). To file a complaint of discrimination, write to USDA, Director, Office of Civil Rights, 1400 Independence Avenue, S.W., Washington, D.C. 20250-9410, or call (800) 795-3272 (voice) or (202) 720-6382 (TDD). USDA is an equal opportunity provider and employer.

* Corresponding author at: USDA - Agricultural Research Service, George E. Brown Jr. Salinity Laboratory, 450 W. Big Springs Rd., Riverside, CA 92507-4617, USA. Tel.: +1951369 4851; fax: +19513424964.

E-mail address: ray.anderson@ars.usda.gov (R.G. Anderson).
}

energy investment (Goldemberg et al., 2008; Waclawovsky et al., 2010), which results in proportionally greater greenhouse gas reductions than other agronomic biofuels (De Vries et al., 2010; Davis et al., 2012). As with other crops, using sugarcane in advanced conversion techniques incentivizes different agronomic qualities (e.g., plant biomass accumulation and enhanced resource use efficiency) versus traditional traits (e.g., maximum sugar yield) (Muchow et al., 1996; Van der Weijde et al., 2013). Growth and efficiency properties that are advantageous for advanced biofuels, such as net biomass accumulation and radiation use efficiency (RUE), have been investigated for sugarcane using micrometeorological (Cabral et al., 2011, 2013), remote sensing (Portz et al., 2011), and field trial/biometric approaches (Inman-Bamber et al., 2011).

Hawaii is one region where cellulosic biofuel crops are being evaluated. The Hawaiian islands have been a significant, highlyproductive, sugarcane region, but most of the commercial operations ceased in the 1980s and 1990s due to economic pressures (Heinz and Osgood, 2009). Following cessation of sugarcane cultivation, these lands have reverted back to pasture 
and forest and have been identified as potential source areas for biofuels (Keffer et al., 2006). Recent emergence of potentially large and stable consumers (e.g., the United States Navy) of advanced biofuels in Hawaii, (Closson, 2013; Steiner, 2012) has spurred renewed interest in growing sugarcane and other high biomass grasses. However, little research on the unique Hawaiian sugarcane system has been done since the decline of the industry and its research organization, the Hawaiian Sugar Planters' Association (Heinz and Osgood, 2009).

Hawaiian sugarcane production is distinguished by two major features compared to other regions. One is the extensive reliance on drip irrigation (Moore and Fitschen, 1990). The other is a much longer growing period ( $\sim 24$ months) compared to other sugarcane growing regions (Allen et al., 1998). Previous studies have found that biomass accumulation (Evensen et al., 1997) and RUE (Muchow et al., 1997) decrease significantly during the 2nd year of growth. However, assessment of biomass and carbon accumulation in these highly productive environments is challenging, especially in the 2nd year, due to difficulties in recovering desiccated sugarcane leaves (trash) and accounting for stalk dynamics (Muchow et al., 1997). Assessment of sugarcane productivity and efficiency in Hawaii has relied on plot based studies often with narrower row spacing than commercial plantations (Evensen et al., 1997) that may affect the temporal growth dynamics of sugarcane. These studies have also had widely-spaced (>100 days) periodic sampling, which reduces the resolution of detecting changes in carbon accumulation and RUE in response to crop age and meteorological conditions. Furthermore, climate changes, including reduced frequency of trade winds (Garza et al., 2012) and decreased associated precipitation (Norton et al., 2011), and wide-spread adoption of disease resistant cultivars have occurred in Hawaiian sugarcane systems. The impacts of these changes on biomass accumulation and radiation have not been studied

Eddy covariance (EC) has been used to make non-destructive, highly temporally-resolved, field-scale observations of sugarcane carbon accumulation and controls on growth in rain-fed systems in Australia (Denmead et al., 2009) and Brazil (Cabral et al., 2013). However, to the best of our knowledge, no EC observations have been reported for either irrigated or Hawaiian sugarcane systems. In this study, we used two EC towers in commercial sugarcane fields in Maui, Hawaii with contrasting elevations and soil types in combination with remote sensing and biometric approaches. Our objectives were two-fold. First, we evaluated whether recent climatic changes in Hawaii have changed the temporal pattern of sugarcane RUE and carbon/biomass accumulation. We hypothesize that the drier locations in our study would result in larger biomass accumulation and higher RUE into the 2 nd year of production than previously found due to lower stalk mortality and reduced decay of detritus (also known as trash in sugarcane production literature). Second, we assessed whether the adoption of drip irrigation reduced the impact of soil type and elevation on sugarcane growth and biomass accumulation. Higher-elevation Hawaiian fields have historically had sugarcane rotations up to 36 months to maximize sucrose accumulation (Heinz and Osgood, 2009). Additionally, higher elevation fields tend to have greater slopes which make furrow irrigation practices difficult. We hypothesize that drip irrigation and associated fertigation would enable more precise, site-specific irrigation and fertilization to meet sugarcane growth needs, thus reducing biomass accumulation differences between locations with different soil types and elevations as well as reducing inaccessible below ground biomass growth. Answering these two objectives will help update life cycle analyses (e.g., Davis et al., 2009) for comparison of sugarcane with alternative potential biofuel crops and cultivation practices in Hawaii and elsewhere.

\section{Methods}

\subsection{Study site and cultivation practices}

Our study sites were located on a $\sim 15,000$ ha commercial sugarcane (Saccharum officinarum L.) plantation (hereafter referred to as "the farm") in Central Maui, Hawaii, USA (Fig. 1). More details of the farm and experimental setup can be found in Anderson et al. (2014) and Anderson and Wang (2014). Per common practice in Hawaii (Evensen et al., 1997; Heinz and Osgood, 2009), the farm grows sugarcane on a 24-month cycle. The sugarcane is grown from a seed cane crop and is not ratooned. Many areas of the farm have been in continuous sugarcane cultivation for over 100 years. Due to its predominantly Leeward location, the farm uses drip irrigation (Moore and Fitschen, 1990) to supplement highly spatially variable precipitation that ranges from less than 300 to more than 1200 mmyear $^{-1}$ across the plantation (Giambelluca et al., 2013). Prior to planting, the soil is tilled to a depth of approximately $60 \mathrm{~cm}$ and soil amendments, including lime, mill mud, and sand, are added to balance soil $\mathrm{pH}$ and to fertilize according to commercial practice. Drip irrigation lines are laid out
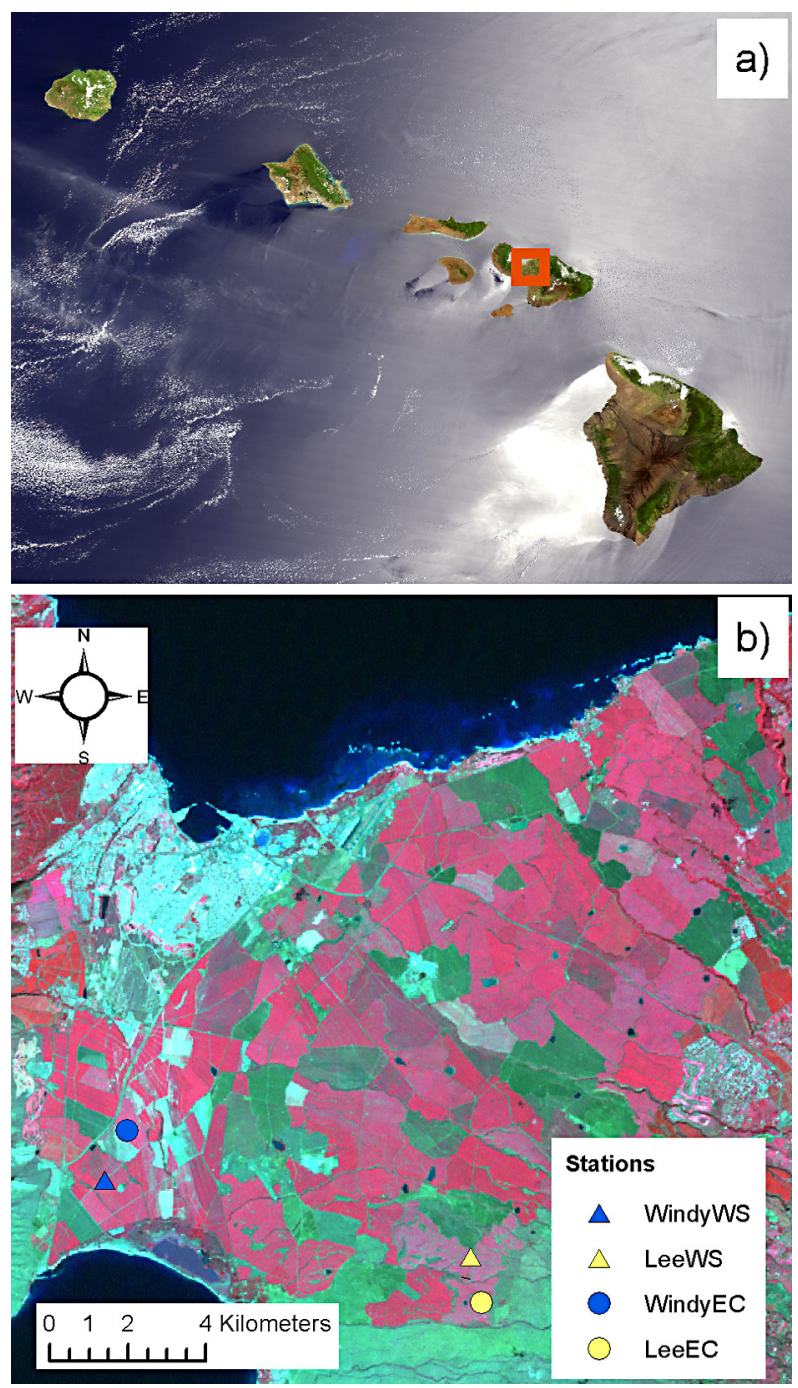

Fig. 1. (a) True color image of the Hawaiian Islands from MODIS - Terra. Study area inset in red box. (b) Landsat 8 false color image (bands 6, 5, and 4 corresponding to red, green, and blue) showing eddy covariance (EC) and weather station (WS) in relation to the farm. (For interpretation of the references to color in this figure legend, the reader is referred to the web version of this article.) 
Table 1

Field characteristics, eddy covariance (EC), and weather station (WS) information presented for both fields. Weather stations were used because EC towers were not equipped with pyranometers. Data collection from EC towers started/stopped on the same dates as EC installation/removal.

\begin{tabular}{lll}
\hline & Windy & Lee \\
\hline EC - latitude $\left({ }^{\circ} \mathrm{N}\right)$ & 20.824633 & 20.784664 \\
EC - longitude $\left({ }^{\circ} \mathrm{W}\right)$ & 156.491278 & 156.403869 \\
EC - elevation $(\mathrm{m})$ & 44 & 203 \\
WS - latitude $\left({ }^{\circ} \mathrm{N}\right)$ & 20.813333 & 20.795361 \\
WS - longitude $\left({ }^{\circ} \mathrm{W}\right)$ & 156.496694 & 156.406444 \\
WS - elevation $(\mathrm{m})$ & 24 & 142 \\
Planting date & May 11, 2011 & March 28,2011 \\
EC installation & July 23, 2011 & July 21, 2011 \\
EC removed & April 19, 2013 & November 7, 2012 \\
USDA soil series (texture) & Pulehu cobbly silt loam (sandy clay loam) & Waiakoa very stony, silty clay loam (clay) \\
\hline
\end{tabular}

at a spacing of $2.70 \mathrm{~m}$ with sugarcane planted on both sides of the line at a distance of $45 \mathrm{~cm}$. Fertilizers (urea, green phosphoric acid, and potassium chloride) are added throughout the first year of growth via the drip system. Prior to harvest, irrigation is reduced to encourage ripening, dry down the crop, and increase sugar content. Fields are burned at harvest to remove excess sugarcane trash (non-stalk residue) prior to hauling cane off of the field. All field management was done by the farm for commercial harvest purposes.

\subsection{Eddy covariance and meteorological observations}

We installed two eddy covariance (EC) towers in production sugarcane fields at two contrasting fields at the farm (Table 1). Full details on the EC tower setup and general data processing procedures, including energy balance and moisture observations, are presented elsewhere (Anderson et al., 2014; Anderson and Wang, 2014). One field (hereafter referred to as "Windy") was a lower-elevation field with a sandy-clay loam soil (Table 1). The second field (hereafter referred to as "Lee") had a higher elevation and a soil with a greater rock and clay content than Windy. Both fields were planted with the same locally-developed sugarcane cultivar, H65-7052 (Heinz et al., 1981), used across the majority of the farm. Instruments in both fields were identical. Our EC tower had an integrated system (EC150, Campbell Scientific Inc., Logan, Utah, USA $^{3}$ ) consisting of an open-path infrared gas analyzer and three-dimensional sonic anemometer with temperature thermistor and enhanced barometer. The tower also had a single component net radiometer (NR-Lite2, Kipp and Zonen, Delft, Netherlands) and air temperature/relative humidity sensor (HMP45C, Vaisala, Vantaa, Finland). All tower instruments were mounted at the same height, which was periodically adjusted to remain 3.0-3.3 $\mathrm{m}$ above the zero-plane displacement (ZPD). ZPD was set as $2 / 3$ of plant canopy height (Arya, 2001), and canopy height was measured every $16 \pm 2$ days. All instruments were factory calibrated prior to deployment, and we calibrated (zeroed and spanned) the infrared gas analyzers in both fields in January 2012 and July 2012.

Raw EC data were collected at $10 \mathrm{~Hz}$. and initially processed on a datalogger (CR3000, Campbell Scientific). Fluxes and other meteorological data were processed into $30 \mathrm{~min}$ averages using with free, open-source software (EddyPro ${ }^{\circledR}$ (v3.0 and v4.0 - advanced mode), released by LI-COR Biosciences, Lincoln, Nebraska USA - http://www.licor.com/eddypro) to post-process the raw, high-frequency data into 30 min fluxes. The software's settings for time-series checks (Vickers and Mahrt, 1997), low and high pass filtering (Moncrieff et al., 1997, 2004), sonic anemometer

\footnotetext{
${ }^{3}$ Mention of trade names or commercial products in this publication is solely for the purpose of providing specific information and does not imply recommendation or endorsement by the U.S. Department of Agriculture.
}

tilt correction with double rotation (Wilczak et al., 2001), and density fluctuations (Webb et al., 1980) were used. Flux footprint lengths (fetch) were calculated using Kljun et al. (2004) method and quality control flags using Mauder and Foken's (2004) approach. Periods during and immediately after rainfall were flagged. Missing or erroneous tower data, as flagged by the software program and processing options specified above, were gap-filled (Falge et al., 2001; Reichstein et al., 2005) using an online tool (http://www.bgc-jena.mpg.de/). We also used the tool to partition the net ecosystem productivity (NEP) fluxes into gross primary productivity (GPP) and ecosystem respiration (Re) using Lloyd and Taylor's (1994) model driven with air temperature. All fluxes were corrected for energy budget closure by regressing daily sums of measured turbulent and radiometric available energy and adjusting all fluxes by the slope of the regression forced through the origin (Anderson and Wang, 2014; Leuning et al., 2012).

As we did not have solar irradiance observations at our EC tower, solar irradiance data were obtained from two nearby weather stations (hereafter referred to as Windy-WS and LeeWS). Both stations are farm-owned with operation, maintenance, annual instrument calibration, and data processing contracted to a commercial company (Table 1 ). Data from the stations' rain gauge (TE525, Texas Electronics, Dallas, Texas, USA) and irradiance observations from a silicon pyranometer (LI200X, LI-COR, Inc.) were us. Both stations are on a $\sim 10 \mathrm{~m}$ pole and within $1500 \mathrm{~m}$ of their respective EC towers with no significant topographic barriers or gradients between them. Weather station data are recorded and compiled by the operator on an hourly and daily basis.

\subsection{Satellite and biometric observations and RUE calculations}

First, we obtained satellite vegetation observations from the MODerate resolution imaging spectroradiometer (MODIS), Terra $250 \mathrm{~m}, 16$ day vegetation product (product ID: MOD13Q1 v.5 Huete et al., 2002). Reflectance and quality data were subsetted for each tower location using the Oak Ridge National Laboratory DAAC MODIS subsetting and visualization tool (http://daac.ornl.gov/cgibin/MODIS/GLBVIZ_1_Glb/modis_subset_order_global_col5.pl). We then used the red and near-infrared bands in MODIS to calculate the Wide Dynamic Range Vegetation Index (WDRVI - Gitelson (2004)) as follows:

WDRVI $=\alpha \times \frac{P_{\mathrm{NIR}}-P_{\mathrm{RED}}}{P_{\mathrm{NIR}}+P_{\mathrm{NED}}}$

where $P_{\mathrm{NIR}}$ and $P_{\mathrm{RED}}$ are reflectances in the near-infrared and red bands, respectively, and $\alpha$ is a semi-empirical coefficient that increases the sensitivity and utility of WDRVI in high biomass environments versus more commonly used vegetation indices (Henebry et al., 2004). An $\alpha$ coefficient of 1 would make Eq. (1) identical to that of the much more widely known Normalized Differential Vegetation Index (NDVI). For WDRVI, the $\alpha$ coefficient 
in the WDRVI calculations was set to 0.2 (Gitelson, 2004), which has been shown to be a suitable tradeoff between increased sensitivity at higher and lower LAIs (Henebry et al., 2004). To calculate LAI, we used Gitelson et al. (2007) linear regression between scaled WDRVI and LAI for maize since maize is similar to sugarcane as a high-biomass agricultural crop and because this linear regression compares well with a universal agricultural regression developed by Nguy-Robertson et al. (2014) across multiple crops and regions (mean LAI error of less than 0.25 across WDRVI range of 0-0.95). The fraction of intercepted solar irradiance was calculated with Beer's law using LAI and a light extinction $(k)$ coefficient (Monsi and Saeki, 2005), with the light extinction coefficient $(k=0.58)$ coming from Inman-Bamber et al. (2011). Of the various reported $k$ coefficients for sugarcane, we chose $k=0.58$ since it is closer to the $k(0.50$ and 0.58$)$ used in MODIS data products (Turner et al., 2005). Dates with clouds or missing data, as flagged by MODIS product visual quality flag, were excluded from further analysis. We interpolated the 16-day observations and calculations of WDRVI, LAI, and fraction of intercepted solar irradiance to daily values using a cubic spline (De Boor, 1978) and then used the daily values to calculate total intercepted solar irradiation.

Periodically, throughout the growth cycle (at tower establishment, 6 months after planting, 12 months after planting, and at harvest), plants were sampled to determine carbon content. Along with these periodic samplings, plant and root biomass data were collected at harvest in both fields after removal of the EC tower and prior to commercial harvest. In both fields, we sampled at four locations in the tower footprint. At each location, aboveground biomass was measured by destructive sampling (cutting) of sugarcane within a $2 \mathrm{~m}^{2}(2 \mathrm{~m} \times 1 \mathrm{~m})$ frame. Fresh biomass was weighed in the field. Moisture content and dry biomass were gravimetrically determined by taking fresh cane samples and drying at $65^{\circ} \mathrm{C}$ for five days.

Root biomass was measured at each above ground sampling location using a $7 \mathrm{~cm}$ diameter mud auger (Signature Series 350.19, AMS Inc., American Falls, Idaho, USA). Soil samples were first taken at three depths $(0-20,20-40$, and $40-80 \mathrm{~cm})$ at three core locations perpendicular to the sugarcane line $(0 \mathrm{~cm}$ - under cane row, $75 \mathrm{~cm}$, and $150 \mathrm{~cm}$ ). Soil cores were then placed into plastic containers, frozen, and shipped in ice chests back to ARS-Parlier for sieving and analysis for carbon content.

At the ARS-Parlier laboratory, frozen soil samples were thawed and hand sieved using a $1.4 \mathrm{~mm}$ mesh sieve to separate roots from soil. We dried root samples overnight $\left(>10 \mathrm{~h}\right.$ ) at $65^{\circ} \mathrm{C}$ to obtain dry biomass. Dried above and below ground biomass was ground to $2 \mathrm{~mm}$ particle size with a mill (Model 174,931, Thomas Scientific, Swedesboro, New Jersey, USA). Ground biomass samples were dry combusted to determine total carbon content (FLASH 2000 NC Analyzer, Thermo Scientific, Pittsburgh, Pennsylvania, USA). To calculate daily and cumulative biomass for radiation use efficiency (RUE) calculations, we first calculated cumulative heterotrophic respiration (Rh) following Cabral et al. (2013) by taking the difference in carbon storage between the harvested biomass and cumulative net ecosystem productivity (NEP) in the Windy field. The ratio of cumulative $\mathrm{Rh}$ to cumulative total ecosystem respiration ( $R e$ ) was then used to calculate daily $R h$. Windy was chosen to assess the $\mathrm{Rh} / \mathrm{Re}$ ratio due to the extremely high quality of nighttime flux data at this site (Anderson and Wang, 2014) and the minimal biomass at the beginning of EC observations (plant high $<15 \mathrm{~cm}$, plant canopy cover $<10 \%$ ). We interpolated the carbon content of plant biomass between plant samplings to convert the sum of NEP and Rh into total biomass. Finally, we used the shoot to total biomass ratio to calculate above ground biomass. To calculate a total daily and cumulative biomass uncertainty, the uncertainty in the $\mathrm{Rh} / \mathrm{Re}$ ratio was propagated together with the uncertainty in NEP following the error aggregation approach of Rodell et al. (2004).

Two forms of RUE were calculated based on the daily tower data. One was biomass RUE (RUEb), which we define as the net efficiency of the crop at converting intercepted solar irradiance (Rs) to above ground biomass usable ( $\mathrm{g}$ dry biomass per $\mathrm{MJ}$ intercepted Rs); this definition assumes that all aboveground biomass can be used for biofuel production and that root biomass is unavailable for conversion. In addition to providing a metric for estimating the net efficiency of production, RUEb can be directly compared to previous reports of RUE in sugarcane (e.g. Muchow et al., 1997; Sinclair and Muchow, 1999). The other form was gross primary RUE (RUEg), which we define as the photosynthetic efficiency of the crop at converting intercepted Rs to gross primary production (g GPP per MJ intercepted Rs), which is more comparable to light use efficiencies used in satellite modeling and monitoring of plant productivity (e.g. Turner et al., 2003) and can provide greater insight into processes controlling productivity. Mean RUE values for the entire crop cycle were calculated from cumulative GPP/biomass and intercepted solar irradiation.

\section{Results}

\subsection{Meteorological observations}

The Eddy Covariance (EC) observations began on 21 July and 23 July, 2011 (113 and 74 days after planting [DAP]), in the Lee and Windy fields, respectively (Table 1 ). Observations continued in both fields until before harvest. The Lee field was harvested early ( $\sim 18$ months age) due to unexpected deterioration of the irrigation system, whereas the Windy field was harvested at normal age ( $\sim 24$ months). Meteorology was similar between the fields, with the exception of wind velocity (Fig. 2). Daily mean air temperature (air T) ranged between 18.5 and $26.7^{\circ} \mathrm{C}$ in Windy with a mean

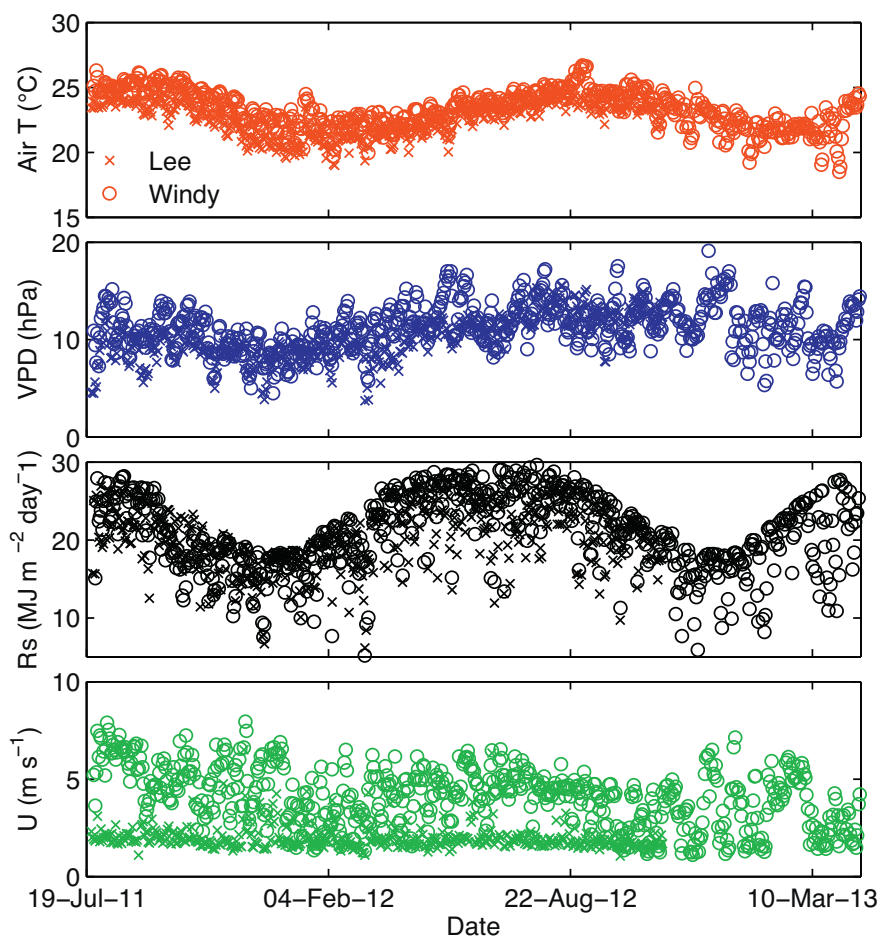

Fig. 2. Daily meteorological data for the eddy covariance (EC) sites, including mean daily air temperature (air $T$ ), mean daily vapor pressure deficit (VPD), daily solar irradiance (Rs), and mean daily wind speed $(U)$. Rs data from cooperators' weather station. All other data come from sensors on EC tower. 


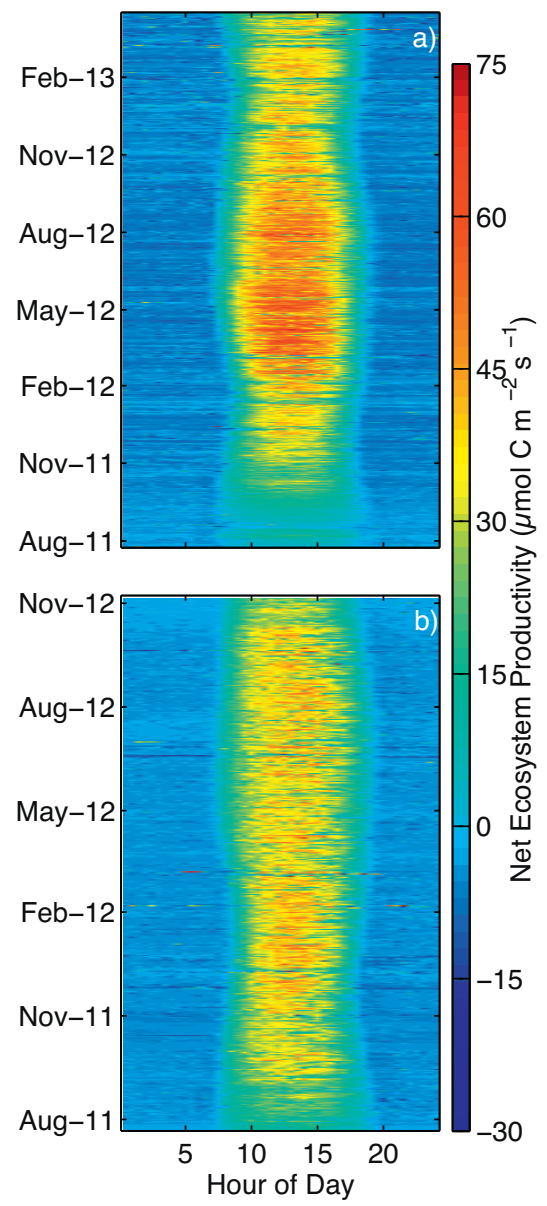

Fig. 3. Fingerprint plots of $30 \mathrm{~min}$ net ecosystem productivity (NEP) fluxes for both EC towers. (a) Windy field. (b) Lee field. Month tick marks indicate the 1st of each month. (standard deviation [STD]) of $23.3(1.45)^{\circ} \mathrm{C}$. In Lee air $T$ ranged from 19.0 to $25.2{ }^{\circ} \mathrm{C}$ with a mean (STD) of $22.6(1.3)^{\circ} \mathrm{C}$. Daily mean vapor pressure deficit (VPD) in both fields was relatively small and showed little seasonal variation. Mean (STD) VPDs in Windy and Lee were 11.3 (2.4) and 10.1 (2.3) hPa, respectively. Solar irradiance (Rs) from the corresponding weather stations showed comparatively greater seasonal variation. Mean (STD) of Rs was 20.8 (4.9) $\mathrm{MJ} \mathrm{m}^{-2}$ day $^{-1}$ in Windy-WS and 20.3 (4.1) $\mathrm{MJ} \mathrm{m}^{-2}$ day $^{-1}$ in Lee-WS. Mean daily wind speed $(U)$ showed the greatest differences between sites; mean (STD) of $U$ was 4.1 (1.5) and $2.0(0.6) \mathrm{m} \mathrm{s}^{-1}$ in Windy and Lee respectively.

Since the EC tower record was significantly (161 days) longer for Windy than Lee we took the overlapping period of the tower to see if there were significant climatic differences between the sites. We analyzed the difference in the mean daily values of all four climate variables (Rs (from Windy-WS and Lee-WS), U, VPD, and air T). All four variables were higher at Windy, with the a mean difference between Windy and Lee for Rs of $1.3 \mathrm{MJ} \mathrm{m}^{-2} \mathrm{day}^{-1}$, for $U$ of $2.4 \mathrm{~m} \mathrm{~s}^{-1}$, for VPD of $1.1 \mathrm{~h} \mathrm{~Pa}$, and for air $T$ of $1.1^{\circ} \mathrm{C}$. To test for statistical difference, we used bootstrapping to sample the difference in daily values for the overlapping period. We used 10,000 samples with replacement for each climate variable. All four variables were very highly significantly different $(p<0.001)$.

\subsection{Net ecosystem productivity, gross primary productivity, and ecosystem respiration}

The 30 min net ecosystem productivity (NEP) fluxes in Windy ranged from -26.3 to $80.5 \mu \mathrm{mol} \mathrm{C} \mathrm{m}^{-2} \mathrm{~s}^{-1}$ with a mean of $8.59 \mu \mathrm{mol} \mathrm{C} \mathrm{m}^{-2} \mathrm{~s}^{-1}$ (Fig. 3a). In Lee the $30 \mathrm{~min}$ NEP ranged from -20.2 to $75.0 \mu \mathrm{mol} \mathrm{C} \mathrm{m}{ }^{-2} \mathrm{~s}^{-1}$ with a mean of $8.14 \mu \mathrm{mol} \mathrm{C} \mathrm{m}^{-2} \mathrm{~s}^{-1}$ (Fig. $3 \mathrm{~b}$ ). To estimate uncertainty in the mean NEP due to random errors, we again used bootstrapping with replacement with 10,000 samples to calculate a $95 \%$ confidence interval $\left(\mathrm{Cl}_{95}\right)$. In Windy, the $\mathrm{Cl}_{95}$ for mean NEP was 7.94-8.35 $\mu \mathrm{mol} \mathrm{Cm}^{-2} \mathrm{~s}^{-1}$, whereas in Lee the $\mathrm{Cl}_{95}$ was 8.39 to $8.81 \mu \mathrm{mol} \mathrm{m}^{-2} \mathrm{~s}^{-1}$. Cumulative NEP in Windy and Lee was $5.37 \pm 0.21 \times 10^{3} \mathrm{~g} \mathrm{C} \mathrm{m}^{-2}$ and $4.23 \pm 0.10 \times 10^{3} \mathrm{~g} \mathrm{C} \mathrm{m}^{-2}$, respectively (Fig. 4). Cumulative NEP

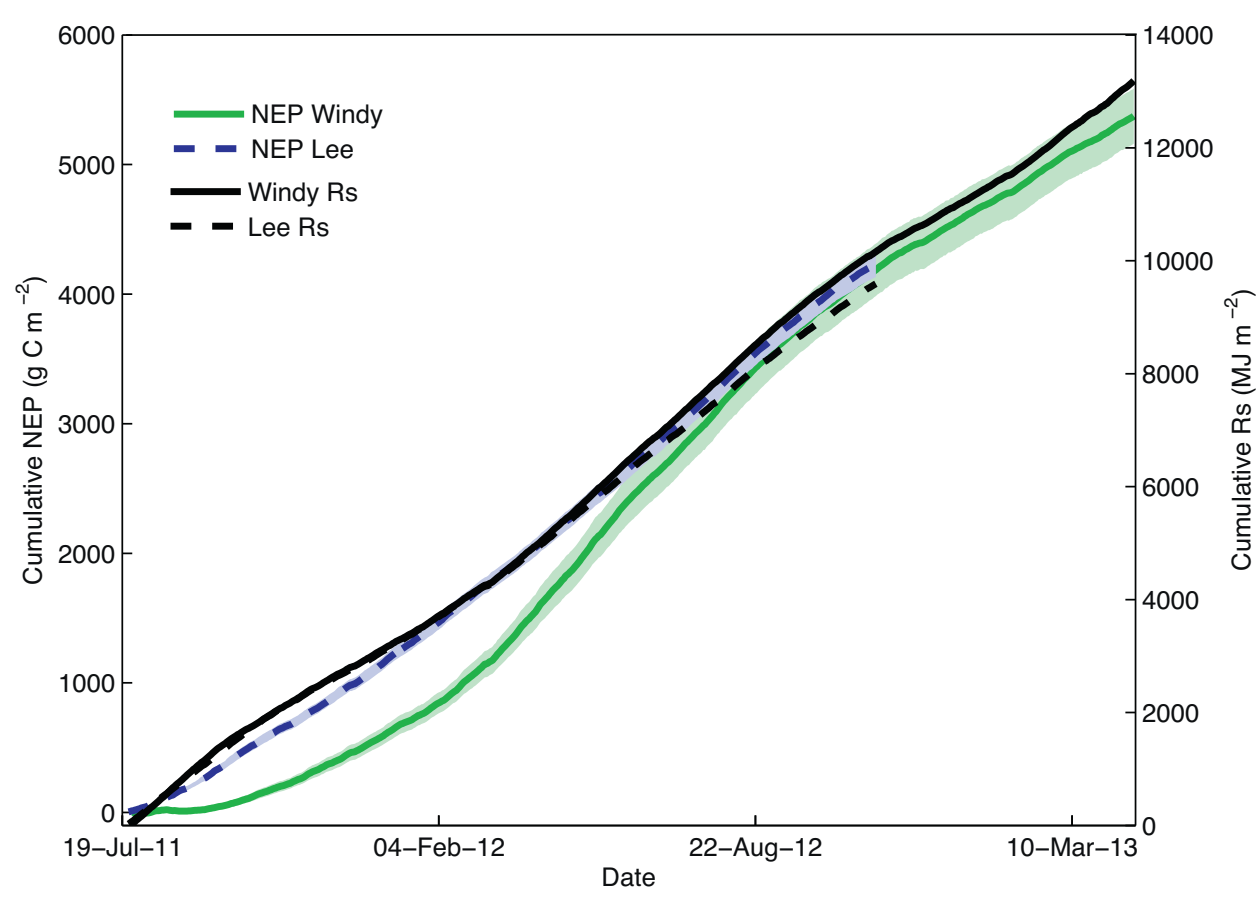

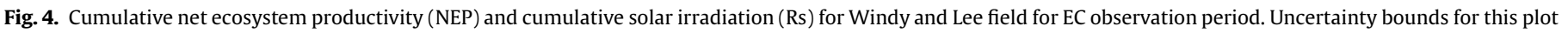
(and subsequent plots) were determined using bootstrapped sampling (10,000 simulations) of daily sums with replacement. 


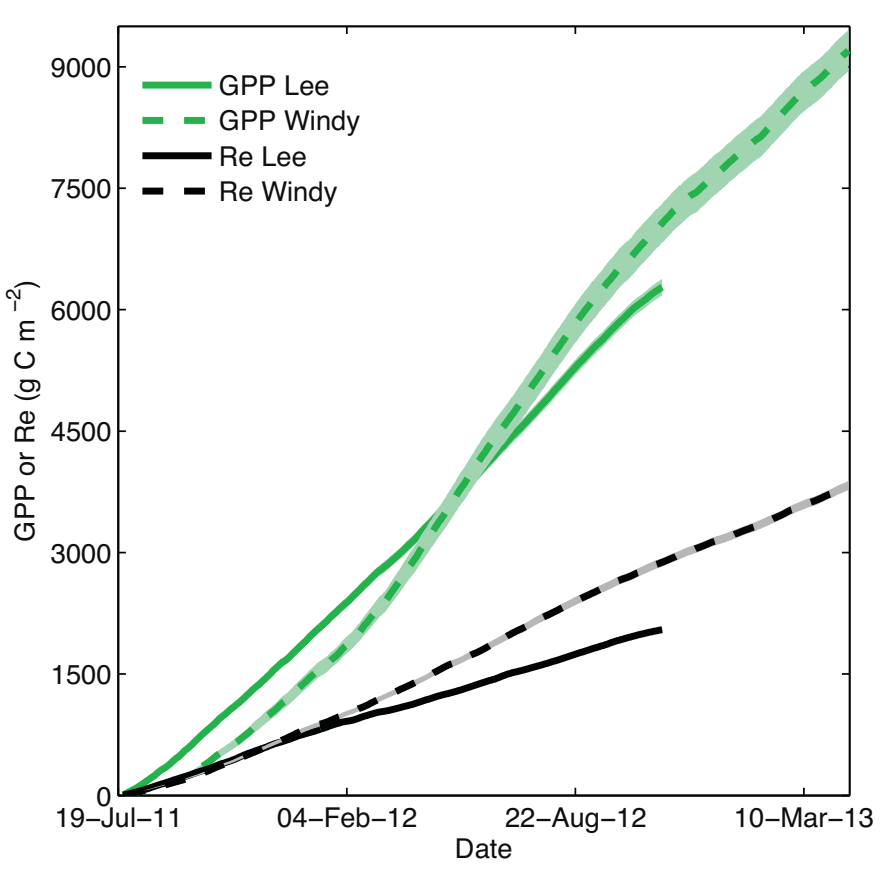

Fig. 5. Cumulative gross primary productivity (GPP) and ecosystem respiration (Re) for Windy and Lee fields for EC observation period.

tracked cumulative solar irradiance (Rs) closely, with Windy having a cumulative Rs of $13.2 \times 10^{3} \mathrm{MJ} \mathrm{m}^{-2}$ and Lee a cumulative Rs of $9.6 \times 10^{3} \mathrm{MJ} \mathrm{m}^{-2}$. The largest divergence between cumulative Rs and NEP occurred in Windy during the early part of the Windy growth cycle due to a greater proportion of Windy's observation period coming during periods of less canopy cover.

Cumulative ecosystem respiration ( $\mathrm{Re}$ ) increased linearly for both fields (Fig. 5), with cumulative Re of $3.82 \pm 0.05 \times 10^{3} \mathrm{~g} \mathrm{C} \mathrm{m}^{-2}$ and $2.05 \pm 0.03 \times 10^{3} \mathrm{gC} \mathrm{m}^{-2}$ in Windy and Lee respectively. Cumulative gross primary productivity (GPP) was $9.21 \pm 0.25 \times 10^{3}$ $\mathrm{g} \mathrm{C} \mathrm{m}^{-2}$ in Windy and $6.28 \pm 0.10 \times 10^{3} \mathrm{~g} \mathrm{C} \mathrm{m}^{-2}$ in Lee. Cumulative

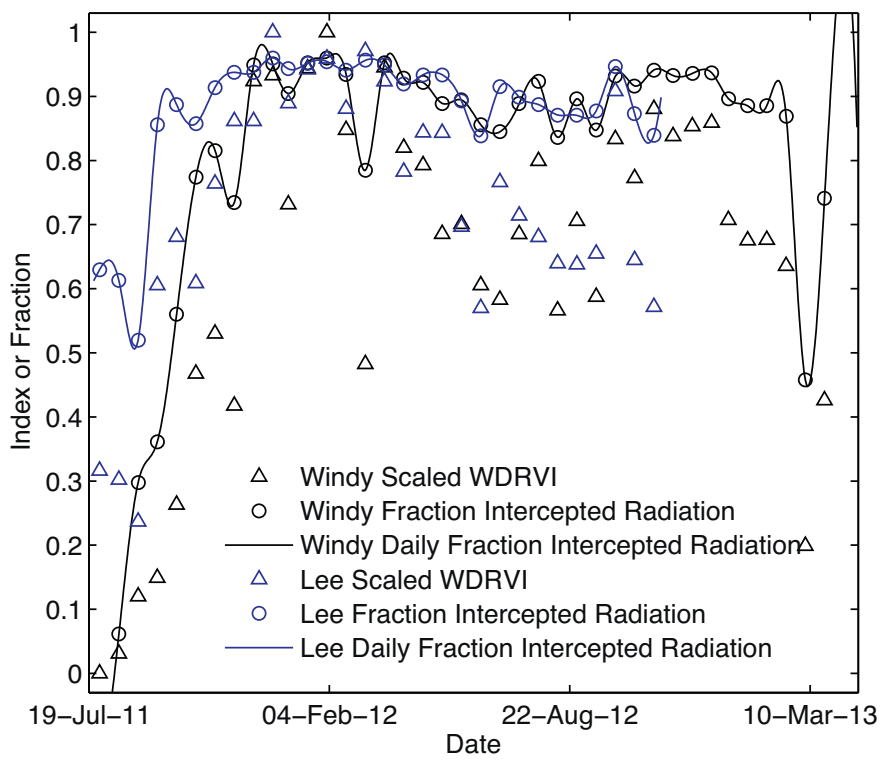

Fig. 6. Wide Dynamic Range Vegetation Index (WDRVI) and fraction of intercepted solar irradiance calculated for both Windy and Lee fields from $250 \mathrm{~m}-16$ day spectral data from the moderate resolution imaging spectroradiometer (MODIS - Terra satellite). Solid line shows daily fraction intercepted irradiance as interpolated using a cubic spline.
GPP increased linearly in Lee and exceeded Windy until mid-May 2012 when Windy overtook Lee (Fig. 5). By the end of the observation period in Lee cumulative GPP and Re in Windy was $7.9 \times 10^{2} \mathrm{~g} \mathrm{C} \mathrm{m}^{-2}$ and $8.3 \times 10^{2} \mathrm{~g} \mathrm{C} \mathrm{m}^{-2}$ higher than Lee.

\subsection{Satellite observations, plant biometry, and radiation use efficiency}

Satellite observations of scaled Wide Dynamic Range Vegetation Index (WDRVI), fraction intercepted radiation, and interpolated daily fraction intercepted radiation are shown in Fig. 6. All indices or fractions showed a predictable increase with increasing crop growth, with Windy showing a greater relative increase due to earlier establishment of the EC tower in the crop cycle. After an initial early peak in fraction intercepted radiation during the winter of 2011-2012, fraction intercepted radiation decreased slightly in summer 2012 prior to increasing back above $90 \%$ in fall 2012. Immediately prior to removal of the EC tower, all of the satellite indices and fractions showed large variation in Windy, which we attributed to the dry-down of the cane prior to harvest. Scaled WDRVI showed greater date to date variation for both fields throughout the entire observation period. LAI (not shown) exceeded 5 in both fields by the beginning of December 2011.

With respect to the biometry observations, the carbon content of biomass in Windy remained constant at 50\%, with only the initial sampling having a slightly lower content of $49 \%$ (Table 3 ). Carbon content in Lee was more variable (46-51\%) and slightly lower (1-3\%) than Windy for all samples except at 6 months. The aboveground biomass as a proportion of total biomass (shoot fraction) was very high in both fields, with 93\% of Lee's biomass and $96 \%$ of Windy's biomass aboveground. The cumulative biometrically observed biomass at harvest (all above ground components plus roots) was $1.39 \pm 0.14 \times 10^{4}$ and $1.13 \pm 0.18 \times 10^{4}$ $\mathrm{g}$ dry biomass $\mathrm{m}^{-2}$ in Windy and Lee respectively. Heterotrophic respiration, as a fraction of total ecosystem respiration (Re), was $35 \%$.

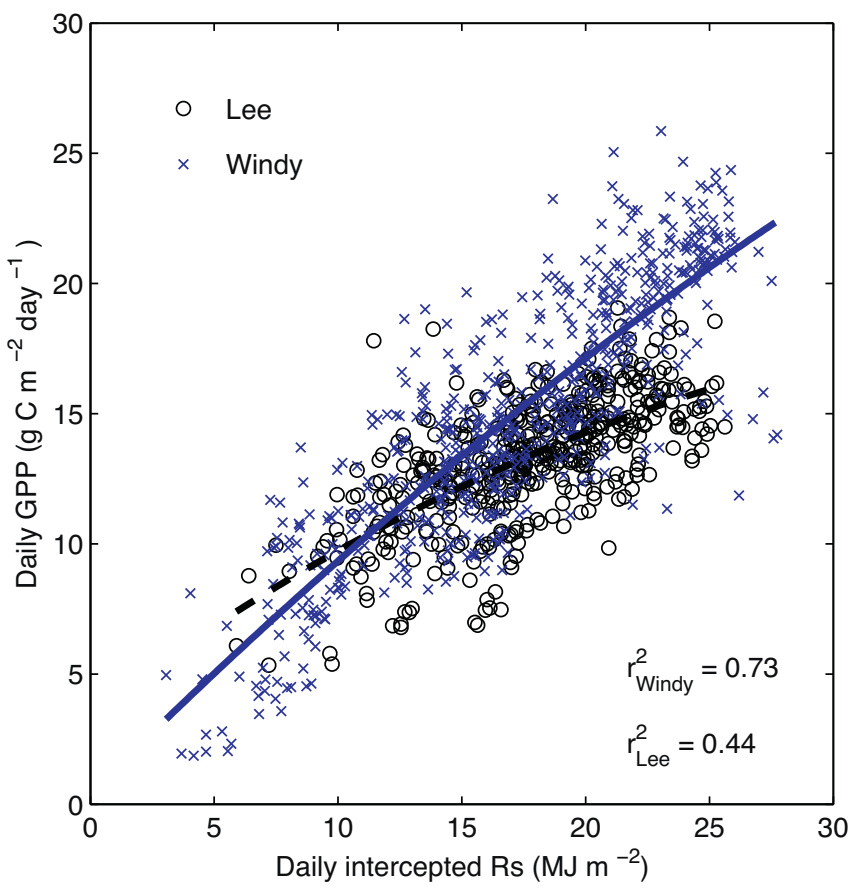

Fig. 7. Daily intercepted solar irradiance (Rs) plotted against daily gross primary productivity (GPP) for both fields. Lines show fitted curve for Windy (solid blue line) and Lee (dotted black line). Daily totals are summed from gap-filled half-hourly data. (For interpretation of the references to color in this figure legend, the reader is referred to the web version of this article.) 


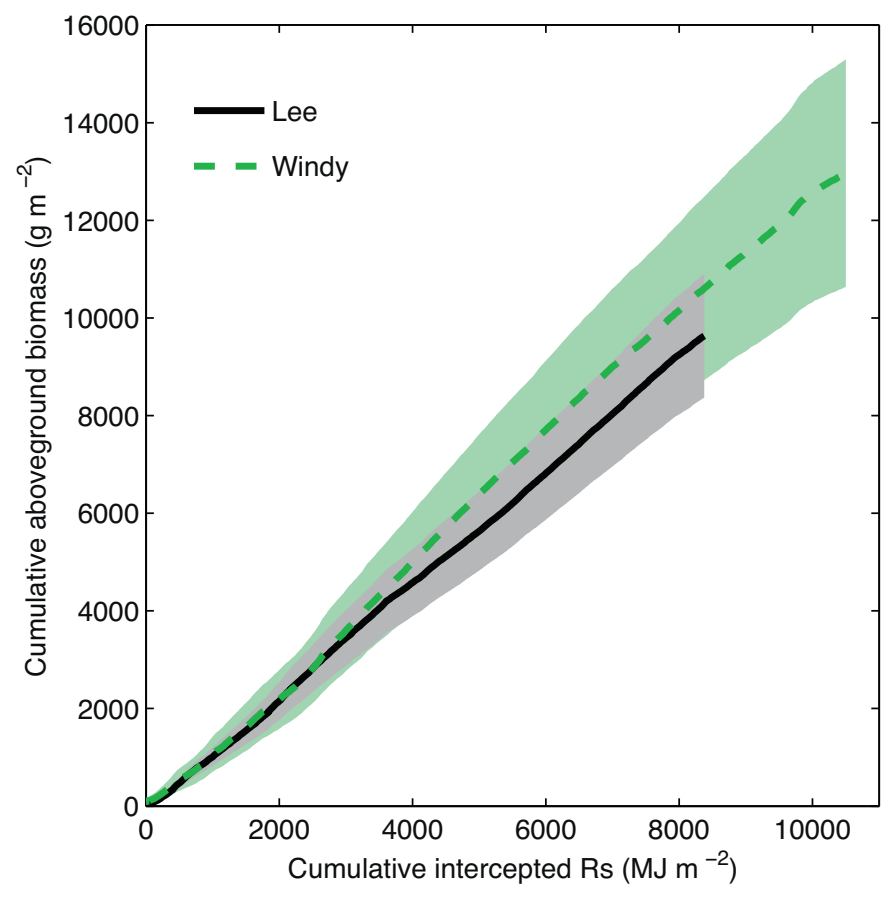

Fig. 8. Cumulative intercepted solar irradiation plotted against cumulative net, above ground biomass accumulation.

Daily intercepted solar irradiance (Rs) ranged from 3.1 to $27.7 \mathrm{MJ} \mathrm{day}^{-1}$ in Windy and 5.9 to $25.6 \mathrm{MJ} \mathrm{day}^{-1}$ in Lee while daily gross primary productivity (GPP) ranged from 1.9 to $25.9 \mathrm{~g} \mathrm{C} \mathrm{m}^{-2}$ and 5.3 to $21.7 \mathrm{~g} \mathrm{C} \mathrm{m}^{-2}$ in Windy and Lee respectively (Fig. 7). We fitted quadratic curves (dotted lines) to both towers to account for the non-linearity between Rs, and tightly associated photosynthetically active radiation (Escobedo et al., 2009), and GPP (Turner et al., 2003). The relationship between intercepted Rs and GPP was significantly stronger in Windy than Lee ( $r^{2}$ of 0.73 versus 0.44$)$, and the response to intercepted Rs was nearly linear in Windy whereas Lee showed less response to increasing Rs on the sunniest days. Averaged over the entire observation period, RUEg was significantly higher in Windy $\left(0.88 \pm 0.02 \mathrm{~g} \mathrm{CMJ}^{-1}\right.$ intercepted Rs) than in Lee $\left(0.75 \pm 0.01 \mathrm{~g} \mathrm{C} \mathrm{MJ}^{-1}\right.$ intercepted Rs $)$. Windy had more calculated cumulative biomass accumulation and intercepted Rs than Lee $\left(1.30 \times 10^{4}\right.$ versus $9.63 \times 10^{3} \mathrm{~g}$ aboveground biomass $\mathrm{m}^{-2}$ and $1.05 \times 10^{4}$ versus $8.37 \times 10^{3} \mathrm{MJ}$ intercepted $\mathrm{Rs} \mathrm{m}^{-2}$ ). However, this difference was primarily due to the longer period that Windy was growing relative to Lee (Fig. 8). Averaged over the entire observation period RUEb in Windy $(1.24 \pm 0.22 \mathrm{~g}$ aboveground biomass $\mathrm{MJ}^{-1}$ intercepted Rs) and Lee $(1.15 \pm 0.15 \mathrm{~g}$ aboveground biomass $\mathrm{MJ}^{-1}$ intercepted Rs) were not significantly different. Furthermore RUEb did not significantly differ between the fields at any time during the growth period (Fig. 8).

\section{Discussion}

\subsection{Comparison of Hawaiian sugarcane productivity and RUE}

On a 30 min basis, peak NEP fluxes in both Windy and Lee were slightly larger $\left(70-80 \mu \mathrm{mol} \mathrm{C} \mathrm{m}^{-2} \mathrm{~s}^{-1}\right)$ than irrigated C4 photosynthetic-pathway agroecosystems in the United States (max. NEP $\sim 70 \mu \mathrm{mol} \mathrm{C} \mathrm{m}^{-2} \mathrm{~s}^{-1}$ - Verma et al., 2005) and higher than productive, rain-fed sugarcane in Brazil and Australia (max. NEP 50-60 $\mu \mathrm{mol} \mathrm{C} \mathrm{m}^{-2} \mathrm{~s}^{-1}$ - Cuadra et al., 2012; Denmead et al., 2009). One major difference compared to previous Hawaiian studies was that no major decrease in the rate of $\mathrm{NEP} /$ biomass accumulation was observed in either field at $\sim 500$ days after planting (DAP), which is counter to Evensen et al.'s (1997) results showing no substantial biomass accumulation after 18 months crop age. Muchow et al. (1997) attributed this decrease in biomass accumulation primarily to increased ecosystem respiration $(\mathrm{Re})$ due stalk death and decay rather than a decrease in gross primary productivity (GPP). However, we did not observe a particularly large increase in cumulative Re or decrease in GPP in the second year of growth (Fig. 5). One possible explanation for suppression of Re is low precipitation. Normal precipitation at Windy and Lee is less than $350 \mathrm{~mm} /$ year (Giambelluca et al., 2013), which is $50 \%$ of normal precipitation at the Oahu study sites used by Evensen et al. (1997) and Muchow et al. (1997). Furthermore, Maui was experiencing significant drought during the observational period; observed precipitation at both adjacent weather stations was less than $160 \mathrm{~mm}$ for the entire 18-24 month period. This lack of rain, combined with drip irrigation using the near or sub-surface drip line, would have protected dead sugarcane stalks and leaves from moisture and thus decomposition, which would have enhanced observed NEP and biomass. Compared to recent micrometeorological observations elsewhere, Hawaiian sugarcane had a higher NEP per cycle compared to Australian $\left(1.6-3.6 \times 10^{3} \mathrm{~g} \mathrm{C} \mathrm{m}^{-2}-\right.$ Denmead et al., 2009) and ratooned Brazilian sugarcane $\left(1.96 \times 10^{3}\right.$ $\mathrm{gC} \mathrm{m}^{-2}$ - Cabral et al., 2013).

Intercomparison of relative radiation use efficiency (RUE) can be challenging between studies due to varying definitions of productivity and parameterizations of radiative input (Sinclair and Muchow, 1999). However, compared to the periodic, peak growing season relative RUE values (1.6-1.9 g biomass $\mathrm{MJ}^{-1}$ intercepted Rs) for sugarcane compiled by Sinclair and Muchow, 1999 (Table 1), our RUE values are lower. There are two possible explanations for this discrepancy we discuss here. First, unlike Muchow et al. (1997), which used the first year of growth for a Hawaiian crop planted in January, we used the entire observation period that encompassed parts of two winters for our sites. More critically, full canopy cover for both fields occurred at the beginning of the 2011-2012 winter. Winter can strongly decrease RUE (Donaldson et al., 2008) and radiation interception (Singels et al., 2005) in sugarcane, with RUE dropping below $0.8 \mathrm{~g}$ biomass $\mathrm{MJ}^{-1}$ intercepted Rs. Second, there is some uncertainty in the parameterization of the light extinction coefficient $(k)$ for calculating intercepted solar irradiance. We chose 0.58 because as of its use in drip-irrigated sugarcane (Inman-Bamber, 1994) and because it is also the value used in MODIS for broadleaf forest vegetation (Turner et al., 2005) that has the most similar LAI to full canopy sugarcane. However, other researchers have found widely varying values for $k$. Muchow et al. (1994, 1997), ) found $k \approx 0.40$ for irrigated cane in Australia and Hawaii while De Silva and Costa (2012) found a low $k$ of 0.27 in irrigated sugarcane in Sri Lanka. Studies that have found lower relative interception (e.g., Muchow et al., 1994; Muchow et al., 1994) have also reported higher RUE

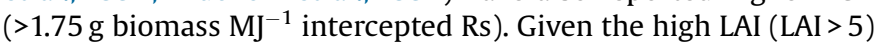
of sugarcane, variation in $k$ should have less impact on calculated fraction of intercepted Rs during the long full-canopy period; however, the impact on early season calculation of intercepted Rs could be significant. To evaluate this, we calculated fraction of intercepted Rs using $k$ values of 0.40 and 0.27 instead of 0.58 to assess the sensitivity of relative RUE. With a $k$ value of 0.40 , RUEb increases by roughly $0.15 \mathrm{~g}$ biomass $\mathrm{MJ}^{-1}$ intercepted Rs (to $1.41 \pm 0.25$ and $1.30 \pm 0.17 \mathrm{~g}$ biomass $\mathrm{MJ}^{-1}$ intercepted Rs in Windy and Lee respectively). With a $k$ value of 0.27 , mean relative RUE increases more to $1.72 \pm 0.31$ and $1.57 \pm 0.21 \mathrm{~g}$ biomass $\mathrm{MJ}^{-1}$ intercepted Rs in Windy and Lee. However, this low of $k$ would result in maximum fraction of intercepted Rs of only 0.7 , which is likely too low given the very low ground heat flux and complete vegetated cover observed by optical cameras at the fields 
(Anderson et al., 2014; Anderson and Wang, 2014). Thus it is likely that the actual $k$ value lies somewhere between 0.4 and 0.58 .

\subsection{Impact of crop cycle length on RUE and productivity}

With increasing focus on total carbon accumulation for advanced biofuels, one possibility for increasing productivity is using alternate cropping practices and cycles. Current practices for Hawaiian sugarcane have little fertilization in the 2 nd year of growth and a reduction in irrigation in the last months prior to harvest. The emphasis is to encourage ripening and sucrose accumulation rather than biomass accumulation (Evensen et al., 1997; Heinz and Osgood, 2009). With no significant variation in RUEb between our fields with differing elevations and soil types and no significant drop off in RUEb with crop age or biomass accumulation, we focus on the amount of Rs intercepted by the crop to maximize productivity. With respect to intercepted Rs, we note that it remains below $\sim 60 \%$ of incident Rs until $\sim 145$ days after planting (DAP) for both Windy and Lee. Neither field declines to that fraction of Rs again with the exception of a possible outlier observation in Windy at the end of the cropping cycle. With a longer cycle between harvests, overall productivity may be higher than other systems (e.g., sugarcane with annual harvest and ratooning). The tradeoff between the lower productivity at the beginning of the growth cycle and the reduced growth phenomenon that has been observed in later growth sugarcane (Van Heerden et al., 2010) needs further exploration to maximize overall field productivity in advanced biofuel systems using Hawaiian sugarcane. We also note that alternate cropping systems, such as ratooning, have well documented issues with diseases and yield declines (e.g., Gillespie and Teakle, 1989; Viswanathan, 2001; Pankhurst et al., 2003; Johnson and Tyagi, 2010). Finally, Hawaiian sugarcane also has a higher portion of total respiration as heterotrophic respiration (35\%) compared to plant (15\%) and ratoon (24\%) crops in Brazil (Cabral et al., 2013), which might indicate faster respiration of soil carbon pools in Hawaii. This might be due to the usually fast (less than one month) turnaround time between sugarcane burning/ harvest and replanting in Hawaii. This potential for enhanced early season respiration is further supported by our early season NEP data from Windy and Lee (Fig. 2). Windy had multiple days early in the observation period with negative NEP (Re greater than GPP) whereas Lee where the tower observations started $\sim 50$ DAP later than Windy, showed no such days with negative NEP.

Our results confirm that Hawaiian sugar cane has a highly favorable carbon balance and net productivity compared to sugarcane systems in other regions of the world. The results also indicate that the current crop cycle length ( $\sim 24$ months) has higher overall biomass productivity than two 12 month cycles. However, we caution that further work is needed with alternate cropping systems (such as ratooning and adding additional fertilizer in the 2nd year of growth) additional cultivars, and in different climatic regimes in Hawaii to obtain the data needed to optimize agronomic practices for advanced biofuel production.

\section{Acknowledgements}

Jim Gartung, Huihui Zhang, Adel Youkhana, Neil Abranyi, and Jason Drogowski assisted with the on-site EC tower installation and maintenance and with collecting plant and soil samples. We thank the farm's agronomic crew (Ronald Cadiz and Justin Lau) and electrical crew for logistical assistance. Matthew Gonzales, Don Tucker, Julianne Anaya, and Phyllis Ukatu provided laboratory assistance and analysis at USDA-ARS, Parlier. This research was supported by USDA - Agricultural Research Service, National Program 211: Water Availability and Watershed Management (project number 5302-13000-011-00) and by the U.S. Navy, Office of Naval Research.

\section{References}

Allen, R.G., Pereira, L.S., Raes, D., Smith, M., 1998. Crop Evapotranspiration: Guidelines for Computing Crop Water Requirements. Food and Agriculture Organization of the United Nations, Rome.

Anderson, R.G., Wang, D., 2014. Energy budget closure observed in paired Eddy Covariance towers with increased and continuous daily turbulence. Agric. For Meteorol. 184, 204-209. doi:http://dx.doi.org/10.1016/j.agrformet.2013.09.012.

Anderson, R.G., Wang, D., Tirado-Corbalá, R., Zhang, H., Ayars, J.E., 2014. Divergence of reference evapotranspiration observations with windy tropical conditions. Hydro. Earth Syst. Sci. Discuss. 11, 6473-6518. doi:http://dx.doi.org/10.5194/ hessd-11-6473-2014.

Arya, S.P., 2001. Introduction to Micrometeorology. Academic Press, San Diego.

Cabral, O.M.R., Rocha, H.R., Gash, J.H., Ligo, M.A.V., Ramos, N.P., Packer, A.P., Batista, E.R., 2013. Fluxes of $\mathrm{CO}_{2}$ above a sugarcane plantation in Brazil. Agric. Forest Meteorol. 182-183, 54-66. doi:http://dx.doi.org/10.1016/j.agrformet.2013.08.004.

Cabral, O.M.R., Rocha, H.R., Gash, J.H., Ligo, M.A.V., Tatsch, J.D., Freitas, H.C., Brasilio, E., 2011. Water use in a sugarcane plantation. GCB Bioenergy 4, 555-565. doi: http://dx.doi.org/10.1111/j 1757-1707.2011.01155.x.

Closson, S., 2013. The military and energy: moving the United States beyond oil. Energy Policy 61, 306-316. doi:http://dx.doi.org/10.1016/j.enpol.2013.05.102.

Cuadra, S.V., Costa, M.H., Kucharik, C.J., Da Rocha, H.R., Tatsch, J.D., Inman-Bamber G., Da Rocha, R.P., Leite, C.C., Cabral, O.M.R., 2012. A biophysical model of sugarcane growth. GCB Bioenergy 36-48. doi:http://dx.doi.org/10.1111/j17571707.2011.01105.x.

Davis, S.C., Anderson-Teixeira, K.J., DeLucia, E.H., 2009. Life-cycle analysis and the ecology of biofuels. Trends Plant Sci. 14, 140-146. doi:http://dx.doi.org/10.1016/ j.tplants.2008.12.006.

Davis, S.C., Parton, W.J., Grosso, S.J.D., Keough, C., Marx, E., Adler, P.R., DeLucia, E.H. 2012. Impact of second-generation biofuel agriculture on greenhouse-gas emissions in the corn-growing regions of the US. Front. Ecol. Environ. 10, 69-74. doi:http://dx.doi.org/10.1890/110003.

De Boor, C., 1978. A Practical Guide to Splines, Applied Mathematical Sciences. Springer-Verlag, New York.

De Silva, A.L.C., Costa, W.A.J.M., 2012. Growth and radiation use efficiency of sugarcane under irrigated and rain-fed conditions in Sri Lanka. Sugar Tech 14, 247-254. doi:http://dx.doi.org/10.1007/s12355-012-0148-y.

De Vries, S.C., van de Ven, G.W.J., van Ittersum, M.K., Giller, K.E., 2010. Resource use efficiency and environmental performance of nine major biofuel crops, processed by first-generation conversion techniques. Biomass Bioenergy 34, 588-601. doi:http://dx.doi.org/10.1016/j.biombioe.2010.01.001.

Denmead, O.T., MacDonald, B.C.T., White, I., Griffith, D.W.T., Bryant, G., Naylor, T., Wilson, S.R., 2009. Evaporation and carbon dioxide exchange by sugarcane crops. Proc. Aust. Soc. Sugar Cane Technol. 31, 116-124.

Donaldson, R.A., Redshaw, K.A., Rhodes, R., Van Antwerpen, R.,2008. Season effects on productivity of some commercial South African sugarcane cultivars, I: Biomass and radiation use efficiency. Proc. S. Afr. Sug. Technol. Ass.

Escobedo, J.F., Gomes, E.N., Oliveira, A.P., Soares, J., 2009. Modeling hourly and daily fractions of UV, PAR and NIR to global solar radiation under various sky conditions at Botucatu, Brazil. Appl. Energy 86, 299-309. doi:http://dx.doi.org/ 10.1016/j.apenergy.2008.04.013.

Evensen, C.I., Muchow, R.C., El-Swaify, S.A., Osgood, R.V., 1997. Yield accumulation in irrigated sugarcane: I. Effect of crop age and cultivar. Agron. J. 89, 638. doi: http://dx.doi.org/10.2134/agronj1997.00021962008900040016x.

Falge, E., Baldocchi, D., Olson, R., Anthoni, P., Aubinet, M., Bernhofer, C., Burba, G., Ceulemans, R., Clement, R., Dolman, H., Granier, A., Gross, P., Grünwald, T., Hollinger, D., Jensen, N.-O., Katul, G., Keronen, P., Kowalski, A., Ta Lai Law, C.B. E., Meyers, T., Moncrieff, J., Moors, E., William Munger, J., Pilegaard, K., Rannik Ü, Rebmann, C., Suyker, A., Tenhunen, J., Tu, K., Verma, S., Vesala, T., Wilson, K., Wofsy, S., 2001. Gap filling strategies for long term energy flux data sets. Agric. For. Meteorol. 107, 71-77. doi:http://dx.doi.org/10.1016/S0168-1923(00) 235-5.

Garza, J.A., Chu, P.-S., Norton, C.W., Schroeder, T.A., 2012. Changes of the prevailing trade winds over the islands of Hawaii and the North Pacific. J. Geophys. Res. 11, 7. doi:http://dx.doi.org/10.1029/2011JD016888.

Giambelluca, T.W., Chen, Q., Frazier, A.G., Price, J.P., Chen, Y.-L., Chu, S., Eischeid, J.K., Delparte, D.M., 2013. Online rainfall atlas of Hawai'i. Bull. Am. Meteorol. Soc. 94, 313-316. doi:http://dx.doi.org/10.1175/BAMS-D-11-00228.1.

Gillespie, A.G., Teakle, D.S., 1989. Ratoon stunting disease. Diseases of Sugarcane: Major Diseases. Elsevier, Amsterdam; New York, pp. 58-80.

Gitelson, A.A., 2004. Wide dynamic range vegetation index for remote quantification of biophysical characteristics of vegetation. J. Plant Physiol. 161, 165-173. doi:http://dx.doi.org/10.1078/0176-1617-01176.

Gitelson, A.A., Wardlow, B.D., Keydan, G.P., Leavitt, B., 2007. An evaluation of MODIS 250-m data for green LAI estimation in crops. Geophys. Res. Lett. 34. doi:http:// dx.doi.org/10.1029/2007GL031620.

Goldemberg, J., Coelho, S.T., Guardabassi, P., 2008. The sustainability of ethanol production from sugarcane. Energy Policy 36, 2086-2097. doi:http://dx.doi.org/ 10.1016/j.enpol.2008.02.028.

Heinz, D.J., Osgood, R.V., 2009. A History of the Experiment Station: Hawaiian Sugar Planters' Association. Hawaiian Planters' Record 61, 1-108.

Heinz, D.J., Tew, T.L., Meyer, H.K., Wu, K.K., 1981. Registration of H65-7052 Sugarcane (Reg. No. 51). Crop Sci. 21, 634. doi:http://dx.doi.org/10.2135/cropsci1981.0011183X00210040050x. 
Henebry, G.M., Viña, A., Gitelson, A.A., 2004. The wide dynamic range vegetation index and its potential utility for gap analysis. Gap Analysis Bulletin. US Geological Survey (No. 12).

Huete, A., Didan, K., Miura, T., Rodriguez, E., Gao, X., Ferreira, L., 2002. Overview of the radiometric and biophysical performance of the MODIS vegetation indices. Remote Sens. Environ. 83, 195-213. doi:http://dx.doi.org/10.1016/S0034-4257 (02)96-2.

Inman-Bamber, N.G., 1994. Temperature and seasonal effects on canopy development and light interception of sugarcane. Field Crops Res. 36, 41-51. doi:http:// dx.doi.org/10.1016/0378-4290(94)90051-5.

Inman-Bamber, N.G., Jackson, P.A., Hewitt, M., 2011. Sucrose accumulation in sugarcane stalks does not limit photosynthesis and biomass production. Crop Pasture Sci. 62, 848. doi:http://dx.doi.org/10.1071/CP11128.

Johnson, S.S., Tyagi, A.P., 2010. Effect of ratoon stunting disease (RSD) on sugarcane yield in Fiji. S. Pac. J. Nat. Appl. Sci. 28, 69. doi:http://dx.doi.org/10.1071/ SP10008.

Keffer, V., Evans, D., Turn, S.,2006. Potential for Ethanol Production in Hawaii.

Kljun, N., Calanca, P., Rotach, M.W., Schmid, H.P., 2004. A Simple Parameterisation for Flux Footprint Predictions. Boundary-Lay. Meteorol. 112, 503-523. doi: http://dx.doi.org/10.1023/B:BOUN.30,653.71031.96.

Leuning, R., van Gorsel, E., Massman, W.J., Isaac, P.R., 2012. Reflections on the surface energy imbalance problem. Agric. For. Meteorol. 156, 65-74. doi:http://dx.doi. org/10.1016/j.agrformet.2011.12.002.

Lloyd, J., Taylor, J.A., 1994. On the temperature dependence of soil respiration. Funct. Ecol. 8, 315-323. doi:http://dx.doi.org/10.2307/2389824.

Mauder, M., Foken, T., 2004. Documentation and Instruction Manual of the Eddy Covariance Software Package TK2. Universitätsbibliothek Bayreuth, Bayreuth.

Moncrieff, J., Clement, R., Finnigan, J., Meyers, T., 2004. Averaging detrending, and filtering of eddy covariance time series. In: Lee, X., Massman, W., Law, B. (Eds.), Handbook of Micrometeorology. Kluwer Academic Publishers, Dordrecht, pp. 7-31.

Moncrieff, J.B., Massheder, J.M., de Bruin, H., Elbers, J., Friborg, T., Heusinkveld, B., Kabat, P., Scott, S., Soegaard, H., Verhoef, A., 1997. A system to measure surface fluxes of momentum, sensible heat, water vapour and carbon dioxide. J. Hydrol. 3, 188-189. doi:http://dx.doi.org/10.1016/S0022-1694(96)3,194-0.

Monsi, M., Saeki, T., 2005. On the factor light in plant communities and its importance for matter production. Ann. Bot. 95, 549-567. doi:http://dx.doi.org/ 10.1093/aob/mci052.

Moore, R.C., Fitschen, J.C., 1990. The drip irrigation revolution in the Hawaiian sugarcane industry. Visions of the Future: Proceedings of the 3. National Irrigation Symposium, Held in Conjunction with the 11. Annual International Irrigation Exposition, 1990. Phoenix Civic Plaza, Phoenix, Arizona, ASAE, St. Joseph, Mich.

Muchow, R., Spillman, M., Wood, A., Thomas, M., 1994. Radiation interception and biomass accumulation in a sugarcane crop grown under irrigated tropical conditions. Aust. J. Agric. Res. 45, 37. doi:http://dx.doi.org/10.1071/AR9940037.

Muchow, R.C., Evensen, C.I., Osgood, R.V., Robertson, M.J., 1997. Yield accumulation in irrigated sugarcane: II. Utilization of intercepted radiation. Agron. J. 89, 646. doi:http://dx.doi.org/10.2134/agronj1997.00021962008900040017x.

Muchow, R.C., Robertson, M.J., Wood, A.W., 1996. Growth of sugarcane under high input conditions in tropical Australia. II. Sucrose accumulation and commercial yield. Field Crops Res. 48, 27-36. doi:http://dx.doi.org/10.1016/0378-4290(96) 42-1.

Nguy-Robertson, A.L., Peng, Y., Gitelson, A.A., Arkebauer, T.J., Pimstein, A. Herrmann, I., Karnieli, A., Rundquist, D.C., Bonfil, D.J., 2014. Estimating green LAI in four crops: potential of determining optimal spectral bands for a universal algorithm. Agric. For. Meteorol. 192-193, 140-148. doi:http://dx.doi.org/ 10.1016/j.agrformet.2014.03.004.

Norton, C.W., Chu, P.-S., Schroeder, T.A., 2011. Projecting changes in future heavy rainfall events for Oahu, Hawaii: a statistical downscaling approach. J. Geophys. Res. 11, 6. doi:http://dx.doi.org/10.1029/2011JD015641.

Pankhurst, C., Magarey, R., Stirling, G., Blair, B., Bell, M., Garside, A., 2003. Management practices to improve soil health and reduce the effects of detrimental soil biota associated with yield decline of sugarcane in Queensland, Australia. Soil Tillage Res. 72, 125-137. doi:http://dx.doi.org/10.1016/S01671987(03)83-7.

Portz, G., Molin, J.P., Jasper, J., 2011. Active crop sensor to detect variability of nitrogen supply and biomass on sugarcane fields. Precis. Agric. 13, 33-44. doi: http://dx.doi.org/10.1007/s11119-011-9243-4.

Reichstein, M., Falge, E., Baldocchi, D., Papale, D., Aubinet, M., Berbigier, P. Bernhofer, C., Buchmann, N., Gilmanov, T., Granier, A., Grunwald, T., Havrankova, K., Ilvesniemi, H., Janous, D., Knohl, A., Laurila, T., Lohila, A., Loustau, D. Matteucci, G., Meyers, T., Miglietta, F., Ourcival, J.-M., Pumpanen, J., Rambal, S. Rotenberg, E., Sanz, M., Tenhunen, J., Seufert, G., Vaccari, F., Vesala, T., Yakir, D., Valentini, R., 2005. On the separation of net ecosystem exchange into assimilation and ecosystem respiration: review and improved algorithm. Glob. Change Biol. 11, 1424-1439. doi:http://dx.doi.org/10.1111/j 1365-2486.2005.001002.x

Rodell, M., Famiglietti, J.S., Chen, J., Seneviratne, S.I., Viterbo, P., Holl, S., Wilson, C.R., 2004. Basin scale estimates of evapotranspiration using GRACE and other observations. Geophys. Res. Lett. 31, L20504. doi:http://dx.doi.org/10.1029/ 2004 GL020873.

Sinclair, T.R., Muchow, R.C., 1999. Radiation use efficiency. Advances in Agronomy. Elsevier, pp. 215-265.

Singels, A., Smit, M.A., Redshaw, K.A., Donaldson, R.A., 2005. The effect of crop start date, crop class and cultivar on sugarcane canopy development and radiation interception. Field Crops Res. 92, 249-260. doi:http://dx.doi.org/10.1016/j. fcr.2005.01.028.

Steiner, J.L., 2012. Biofuels: no single answer, many possibilities. Agric. Res. 2.

Turner, D.P., Ritts, W.D., Cohen, W.B., Maeirsperger, T.K., Gower, S.T., Kirschbaum, A A., Running, S.W., Zhao, M., Wofsy, S.C., Dunn, A.L., Law, B.E., Campbell, J.L., Oechel, W.C., Kwon, H.J., Meyers, T.P., Small, E.E., Kurc, S.A., Gamon, J.A., 2005. Site-level evaluation of satellite-based global terrestrial gross primary production and net primary production monitoring. Glob. Change Biol. 666-684. doi:http://dx.doi.org/10.1111/j 1365-2486.2005.00936.x.

Turner, D.P., Urbanski, S., Bremer, D., Wofsy, S.C., Meyers, T., Gower, S.T., Gregory, M., 2003. A cross-biome comparison of daily light use efficiency for gross primary production. Glob. Change Biol. 383-395. doi:http://dx.doi.org/10.1046/j 13652486.2003.00573.x.

Van der Weijde, T., Alvim Kamei, C.L., Torres, A.F., Vermerris, W., Dolstra, O., Visser R.G.F., Trindade, L.M., 2013. The potential of C4 grasses for cellulosic biofuel production. Front. Plant Sci. 4. doi:http://dx.doi.org/10.3389/fpls.2013.00107.

Van Heerden, P.D.R., Donaldson, R.A., Watt, D.A., Singels, A., 2010. Biomass accumulation in sugarcane: unravelling the factors underpinning reduced growth phenomena. J. Exp. Bot. 61, 2877-2887. doi:http://dx.doi.org/10.1093/ jxb/erq144.

Verma, S.B., Dobermann, A., Cassman, K.G., Walters, D.T., Knops, J.M., Arkebauer, T.J., Suyker, A.E., Burba, G.G., Amos, B., Yang, H., Ginting, D., Hubbard, K.G., Gitelson, A.A., Walter-Shea, E.A., 2005. Annual carbon dioxide exchange in irrigated and rainfed maize-based agroecosystems. Agric. For. Meteorol. 131, 77-96. doi: http://dx.doi.org/10.1016/j.agrformet.2005.05.003.

Vickers, D., Mahrt, L., 1997. Quality control and flux sampling problems for tower and aircraft data. J. Atmos. Oceanic Technol. 14, 512-526. doi:http://dx.doi.org/ 10.1175/1520-0426(1997)0142.0.CO;2.

Viswanathan, R., 2001. Growing severity of ratoon stunting disease of sugarcane in India. Sugar Technol. 3, 154-159. doi:http://dx.doi.org/10.1007/BF02956808.

Waclawovsky, A.J., Sato, P.M., Lembke, C.G., Moore, P.H., Souza, G.M., 2010 Sugarcane for bioenergy production: an assessment of yield and regulation of sucrose content. Plant Biotechnol. J. 8, 263-276. doi:http://dx.doi.org/10.1111/j 1467-7652.2009.00491.x.

Webb, E.K., Pearman, G.I., Leuning, R., 1980. Correction of flux measurements for density effects due to heat and water vapour transfer. Q. J. R. Meteorolog. Soc. 106, 85-100. doi:http://dx.doi.org/10.1002/qj.49710644707.

Wilczak, J., Oncley, S., Stage, S., 2001. Sonic anemometer tilt correction algorithms. Boundary-Lay. Meteorol doi:http://dx.doi.org/10.1023/A.1018966204465. 